\title{
Impact of storage temperature and duration on the nutritive content quality of Human Breastmilk
}

\author{
Gihan FAhmad1, Naglaa M Mostafa2, Tayseer MA EIZayat3, Ghada Z \\ Soliman1, Eman A Al Morsi 3and Eman M Elhabashi4
}

\author{
1. National Nutrition Institute, Cairo- Egypt \\ 2. Abu Al-Nomros central hospital \\ 3. Faculty of Medicine for Girls- Al-Azhar University, Cairo- Egypt \\ 4. Faculty of Medicine- Cairo University, Kasr-Alainy Street, Cairo- Egypt
}

Corresponding Author: Eman Moawad Elhabashi, Lecturer of Public health and Community Medicine, Faculty of Medicine- Cairo University Tel.: (+2) 01001025524, Postal: P.O.Box 24 Eldokki, Giza, E-mail address: Iman.Al-Habashi@kasralainy.edu.eg; Eman_Moawad@hotmail.com

\section{ABSTRACT}

$W$ orld Health Organization recommends exclusive breastfeeding, for the first six months of the infant's life, due to the unique composition of breast milk (BM). For working nursing mothers, practicing exclusive breastfeeding can be a challenge. Objectives: To assess the effect of storing BM at different temperatures and durations on selected macronutrients and micronutrients content. Methods: Sixty BM samples were collected in sterile polypropylene containers from twenty mothers at the National Nutrition Institute. Samples from each mother were divided into 3 sets: the first was analyzed immediately, the second were analyzed after storage in refrigerator first shelf $\left(4: 6^{\circ} \mathrm{C}\right)$ for 24 hours, the third were analyzed after storage in the freezer $\left(-4:-8^{\circ} \mathrm{C}\right)$ for one week. Results: Refrigeration resulted in a statistically significant decrease in the Vitamin $A$ and $C$ content of BM while freezing resulted in a statistically significant decrease in Lactose, Vitamin A, C, and $E$ content of BM. Despite all declines in the studied macronutrients and micronutrients, their concentrations remained within the acceptable international reference ranges. Conclusion: Breastfeeding practice should not be stopped or replaced. Changes found in stored BM were found to be of little significance from the nutrition point of view.

Key Words: Breast Milk; Storage; Infant; lactation 
Gihan FAhmad, Naglaa M Mostafa, Tayseer MA ElZayat, Ghada Z Soliman1, Eman A Al Morsi and Eman M Elhabashi

\section{INTRODUCTION:}

Breast milk has all the nutrients newborn demands in the first six months of his life. Along with breastfeeding, practice provides countless health benefits for the mother as well as her infant. The World Health Organization (WHO 2011 \& 2019) considers human Breast milk as the optimal nutrition and ideal mix of nutrients that can be delivered to every full-term healthy infant for at least 6 months. Therefore, WHO recommends that infants must be exclusively breastfed for the first six months of their lives to aid in their proper growth and development and to serve as the foundation of health throughout their life. The concept of 'Exclusive breastfeeding" depends on feeding infants aging from zero to six months oldonly human breast milk with nofluids - not even water -nor any food items with the exception of medications and supplementations such as oral rehydration solution, or drops/syrups of vitamins and minerals when needed (WHO 2011 \& 2019). According to the Egyptian Demographic Health Survey (EDHS 2014), it was revealed that even though $96 \%$ of infants are ever breastfed; but, only $13 \%$ of infants are exclusively breastfed (EDHS 2014).
A huge challenging situation that is facing almost all employed nursing mothers is how to balance between sustaining breastfeeding in general. In addition, exclusive breastfeeding in particular and their paid work, thus increasing the possibility of early termination of breastfeeding (Guendelman et al., 2009). Several factors contribute and guide a woman's decision to exclusively breastfeed, for an example; short maternity leave, early return to work, strict work schedule and working hours, lack of privacy and support at work (Walingo et al., 2014; Zhang et al., 2015; and Thu et al., 2009. Another raised obstacle to maintain successful lactation is separating a mother from her infant due to illness, hence the importance of finding alternatives to feed the separated infants and to maintain breast milk secretion and storage ${ }^{1}$ (Ogbuanu et al., 2011). Nevertheless, the temperature of storage, the storage container and the heating process may influence the nutritional components of human milk (Hamosh et al., 1996; and Lawrence et al., 1999).

\begin{tabular}{l}
\hline The pediatrician supports \\
breastfeeding. Breastfeed Med. 2010; \\
5(5):235-236 pmid: 20942709
\end{tabular}


Gihan FAhmad, Naglaa M Mostafa, Tayseer MA ElZayat, Ghada Z Soliman1, Eman A Al Morsi and Eman M Elhabashi

Investigating the impact of storing breast milk on its nutrients' concentration is necessary for the welfare of breastfed infants. It is important to understand that once human milk is collected, stored, frozen, and thawed, it may go through qualitative and quantitative changes that render it significantly different from milk obtained by an infant during normal suckling (Vieira $\boldsymbol{e t}$ al., 2011). The present study aimed to determine the effect of storage of breast milk for different durations and temperatures, on a number of its chemical constituents, namely total proteins, total fats, lactose, vitamin $\mathrm{C}$, vitamin $\mathrm{A}$ and vitamin $\mathrm{E}$.

\section{METHODS}

This research was an in-vitro experimental study design conducted at National Nutrition Institute from January till mid-February 2016.

\section{Sample Collection:}

Demographic data were collected using an interview-guided questionnaire for an example; maternal age, parity, maternal BMI, gestational age of the infant, infants' ages and ordering of the child.

Twenty human breast milk samples were collected from twenty anonymous mothers attending breast- feeding clinic at the National Nutrition Institute. All participants provided informed consent. Milk samples were collected from the mothers who have babies aged 4 weeks to 24 weeks (6 month). All donors were healthy and gave birth to healthy infants. Simple random sampling method was the used sampling technique to obtain human breast milk samples of the research subject (mothers who fulfilled the research requirements). Each participant mother was instructed to wash her hands carefully with soap and water before collecting milk samples, then to express some of her breast milk -from either the left or right breast- into labeled sterile hard glass containers $(60 \mathrm{ml}$ each) by a sterilized electric expression pump. The samples came from just one extraction $(60 \mathrm{ml})$. Immediately following extraction- within 20-25 minutes, the samples were transferred in an igloo (ice mate) to the analytical laboratory in National Nutrition Institute for chemical analysis and storage.

\section{Sample Preparation and Storage:}

The breast milk samples were collected in sterile hard glass containers, covered with tight caps.The collected expressed breast milk (EBM) samples from each 
Gihan FAhmad, Naglaa M Mostafa, Tayseer MA ElZayat, Ghada Z Soliman1, Eman A Al Morsi and Eman M Elhabashi

mother were divided into 3 sets, each set were divided into another 2 set as one of them is wrapped with aluminum foil as follows:

1) The first sample $(20 \mathrm{ml})$ was analyzed immediately to be considered as the control sample (the baseline for analysis at zero hour).

2) The second sample $(20 \mathrm{ml})$ was stored immediately in the refrigerator, first shelf (4$6^{\circ} \mathrm{C}$ ) for 24 hours then analyzed.

3) The third sample $(20 \mathrm{ml})$ was stored immediately in the freezer $\left(-4\right.$ to $\left.-8^{\circ} \mathrm{C}\right)$ for one week then analyzed.

\section{Sample Analysis:}

For vitamin analysis, the containers were dark or wrapped with aluminum foil to avoid exposure to light. Milk was analysed for its proximate composition: moisture, ash, fat and protein according to AOAC 2016 standard methods (AOAC 2016). Carbohydrate was estimated by difference [100-(Protein+ fat+ moisture)] while fatty acids composition were determined according to the method of Morrison and Smith 1964, ISO 15304 /2002, ISO 12966-2 /2011 and Santos et al., 2015. The content of minerals and vitamins was assayed by means of the AAS flame technique, using a Unicam 929 apparatus (AA Spectrometer Unicam) and HPLC (Shimadzo) respectively using standard methods of AOAC 2016, Analysis was done in triplicate.

\section{Data Analysis:}

Descriptive statistical analysis is presented for the six outcome variables (total fat content, total proteins content, lactose content, and concentrations of Vitamin A, vitamin $\mathrm{C}$ and vitamin $\mathrm{E}$ ).

Data were analysed using SPSS software, specifically using the independent $t$ test and one-way analysis of variance (ANOVA). Significant differences were defined as $P \quad$ value $<0.05$ with a $95 \%$ confidence level.

\section{RESULTS:}

Twenty breast milk samples were obtained from 20 healthy mothers. Mean age of the mothers was 28.7 years (SD \pm 5.98 ). Ninety percent of the mothers were living in urban areas. Nine out of the twenty participating mothers gave birth by Caesarean section. Mean gestational age of their children was 39.10 weeks $(\mathrm{SD} \pm 1.21)$. Sixty percent $(n=12)$ of the infants were females and their 
Gihan FAhmad, Naglaa M Mostafa, Tayseer MA ElZayat, Ghada Z Soliman1, Eman A Al Morsi and Eman M Elhabashi

mean age was 87.70 days (SD $\pm 47.18)$.

Table (1): demonstrates that the researchers at the start compared the baseline fresh breast milk nutrient mean values (at Zero Hour) samples for all the twenty participants mothers with international reference Milk nutrient mean values formacronutrients, vitamins. Although the mean of the baseline values of macronutrients and vitamins studied breast milk samples, were lower than the international mean reference values; but still the nutrient content values were within the international reference nutrient ranges for mature breast milk (Curran et al., 2000).

Table (2) shows the results came out when the researchers analyzed the second patch of the collected breast milk samples after being stored for 24 hours in refrigerator at $\left(4-6^{\circ} \mathrm{C}\right)$ and compared it with the Baseline Mean Values of Breast Milk. Nutrients at Zero Hour, a statistically nonsignificant reduction in fat, protein and lactose content as well as in vitamin $\mathrm{E}$ concentration were found, while a highly statistically significant reduction in vitamin $\mathrm{C}$ concentration and statistically significant reduction in vitamin A concentration were revealed in relation to the baseline fresh breast milk sample at zero hour.

Table (3): displays the comparative results as the researchers analyzed the third patch of the collected breast milk samples after being stored for one weekin freezer at $\left(-4\right.$ to $\left.-8^{\circ} \mathrm{C}\right)$ and compared it, a statistically nonsignificant reduction in fat, protein and lactose content as well as in vitamin $\mathrm{E}$ concentration were found. While a highly statistically significant reduction in vitamin $\mathrm{C}$ concentration andstatistically significant reduction in vitamin A concentration were revealed in relation to the baseline fresh breast milk sample at zero hour.

\section{DISCUSSION}

The present study provides information on the impact of storage temperature and duration on selected human breast milk. Nutrients (total proteins, total fats, lactose, vitamin C, vitamin $\mathrm{A}$ and vitamin $\mathrm{E}$ ) as several studies showed that storage of human milk for later use has impacts on its constituents and may influence it's nutritional components (Hamosh et al., 1996; Lawrence et al., 1999; Chang et al., 2012; and Thatrimontrichia et al., 2015).

Uunlike milk formula, which has a limited standard range of nutrient 
Gihan FAhmad, Naglaa M Mostafa, Tayseer MA ElZayat, Ghada Z Soliman1, Eman A Al Morsi and Eman M Elhabashi

composition. Human breast milk composition varies between nursing mothers according to several maternal and environmental factors. Hence the wide range of international references for nutrient concentrations of mature breast (Curran et al., 2000; Hamosh et al., 1996; Lawrenceet al., 1999; Chang et al., 2012; Chung et al., 2014 and Thatrimontrichia et al., 2015). Despite the fact that there was a significant difference between most of the mean values of the studied EBM nutrients and the international reference mean values yet the nutrient content values in all the samples were found to be within the international reference nutrient ranges for mature breast milk. Learning all about human breast milk composition and its dynamics is considered an essential tool to be able to understand the potential impact of storage and for proper management of infant feeding (Chung et al., 2014).

With reference to all of the above; variations in human breast milk composition may be related to one or more of the following factors; maternal age, maternal diet, parity, breast-feeding routine, stage of lactation, in addition toother environmental factors such as regional differences and may be seasons of the year (Prentice 1996; and Pham et al., 2020).

According to Howard \& Gusterson 2000 and Neville et al., 2001 human breast milk is divided into four stages according to its composition and volume of milk produced. The first three to five days postpartum is the stage of the "colostrum". Then until the end of the second week, it is the stage of the "transitional milk". While afterwards and during full lactation period it is the stage of the "mature milk"; then a fourth stage is added at the end of lactation which is the "involution milk" (Howard and Gusterson 2000 and Neville et al., 2001). In the current study, mature EBM samples were obtained from nursing mothers, whose infants' ages ranged from 30 days up to 180 days.

Regarding fat content in refrigerated breast milk, results revealed a non-significant decline in fat content of breast milk after refrigeration, in the first shelf (4-6C), for 24 hours $(\mathrm{P}=0.71)$, as well as a non-significant decline in fat content of breast milk after freezing (-4 to $8 \mathrm{C})$, for 1 week $(\mathrm{P}=0.43)$. Both declines were considered not effective from the nutritional point of view, as the mean values of fat content in both the 24 hours refrigeratedbreast milkand the 1 week frozen breast milk 
Gihan FAhmad, Naglaa M Mostafa, Tayseer MA ElZayat, Ghada Z Soliman1, Eman A Al Morsi and Eman M Elhabashi

samples were still within the international reference nutrient ranges for mature breast milk.For mature breast milk. Similar findings were reported by a number of researchers (Pardou et al., 1994; and Ezz El-Din et al., 2004) who attributed these results to the lipolysis occurring during storage, lipid peroxidation or most likely due to the adherence of breast milk to the container wall (Chang et al., 2012). In contrast, Pramitasari et al., 2019 reported an increase in the fat content of the refrigerated and frozen breast milk samples under same circumstances, but it was also considered not clinically relevant and was attributed to using different tools and techniques (Pramitasari et al., 2019).

Regarding Protein content in refrigerated breast milk, results revealed a non-significant decline in Protein content of breast milk after refrigeration, in the first shelf (4-6C), for 24 hours $(\mathrm{P}=0.46)$, as well as a non-significant decline in protein content of breast milk after freezing (4 to $-8 \mathrm{C})$, for 1 week $(\mathrm{P}=0.39)$. Once more, both declines were considered not effective from the nutritional point of view, as the mean values of protein content in both the 24 hours refrigerated breast milk and the 1week frozen breast milk samples were still within the international reference nutritive range for mature breast milk. This was in accordance with what Ezz El-Din et al., 2004 reported in their study carried out among 61 healthy lactating mothers attending $\mathrm{Abu} \mathrm{El-}$ Reesh hospital outpatient clinics and Qasr El-Aini neonatal intensive care unit follow-up clinic at Cairo University. Results was in accordance with what Muhammad et al., 2016 stated that the temperature on different types of storage did not affect the levels of protein yet relating the change to the duration of the storage not to be more than 72 hours. Furthermore Lev et al, 2014 revealed in their research whereas the protein content remained unchanged among their participants' samples. Although Pramitasari et al., 2019stated a significant decrease in the protein content of the refrigerated and frozen breast milk samples but both results were still within the international reference nutritive range for mature breast milk which makes it clinically irrelevant. Another study reported increased concentrations of protein content which according to their explanation that it might be due to water evaporation (volatilization), sublimation, and the increased infrared absorbance of protein at the 
Gihan FAhmad, Naglaa M Mostafa, Tayseer MA ElZayat, Ghada Z Soliman1, Eman A Al Morsi and Eman M Elhabashi

5.7- $\mu \mathrm{m}$ wave and over time (Chang $\boldsymbol{e t}$ al., 2012).

Regarding Lactose content in refrigerated breast milk, results revealed a non-significant decline in Lactose content of breast milk after refrigeration, in the first shelf (4-6C), for 24 hours $(P=0.270)$. This was in agreement with several studies showed no clinically significant changes in the lactose content of the refrigerated breast milk sample for 24 hours from the nutritional point of view (Ezz El-Din et al., 2004; Pramitasari et al., 2019; and Muhammad et al., 2016). However, results showed a highly significant decline in Lactose content of breast milk after freezing (-20C), for 1 week $(\mathrm{P}=0.001)$, yet the mean values of lactose content was still within the international reference nutritive range for mature breast milk.

Regarding Vitamins, A, C and $\mathbf{E}$ content in refrigerated breast milk, results revealed a highly significant decline in Vitamins A and $\mathrm{C}$ with a non-significant decline in Vitamin E content of breast milk after refrigeration, in the first shelf (4-6C), for 24 hours $(\mathrm{P}=0.049, \mathrm{P}=0.000$ and $\mathrm{P}=0.09$ respectively). As well as after freezing for both Vitamins $\mathrm{A}$ and $\mathrm{C}$ and a highly significant decline for vitamin $\mathrm{E}$ too after freezing at (-4 to -
$8 \mathrm{C})$, for 1 week $(\mathrm{P}=0.000, \mathrm{P}=0.000$ and $\mathrm{P}=0.000$ respectively). Again, declines were considered of less importance from the nutritional point of view, as the mean values of both vitamins content in both the 24 hours refrigerated breast milk and the 1week frozen breast milk samples were still within the international reference nutritive range for mature breast milk. Many studies found similar results and explained the decline in vitamin $\mathrm{C}$ content because of oxidation of ascorbic acid during storage. It was recommended that milk should be frozen immediately in order to minimize the oxidation process of ascorbic acid and accordingly minimize changes in vitamin $\mathrm{C}$ concentrations (Ezz El-Din et al., 2004; Vieira et al., 2011; Lev et al., 2014; Putu et al., 2019; and Muhammad et al., 2016). While Buss et al., 2001 and Soliman et al., 2020 stated that after 24 hours refrigeration of breast milk, mean vitamin $\mathrm{C}$ concentration showed a significant decline reached $65 \%$ of the initial concentration before storage. Therefore, it was recommended that storage duration of breast milk in refrigerator for less than 24 hours. Usually would preserve $2 / 3$ of the initial vitamin $C$ concentration. If not convenient stored milk, vitamin $\mathrm{C}$ 
Gihan FAhmad, Naglaa M Mostafa, Tayseer MA ElZayat, Ghada Z Soliman1, Eman A Al Morsi and Eman M Elhabashi

supplementation may be considered, and according to Hanna et al., 2004 vitamin $\mathrm{A}, \mathrm{C}$ and $\mathrm{D}$ concentrations were found to be significantly decreased being stored at both refrigeration and freezing temperatures and to preserve these vitamins in breast milk, storing time should be limited to 48 hours. In addition, that refrigeration is better than freezing and thawing.

\section{CONCLUSION}

The study confirms the importance of exclusive breast-feeding for the first six months infant's life. In this regards the results revealed that human breast milk can be stored safely in refrigerator $\left(4-6^{\circ} \mathrm{C}\right)$ for 24 hours and in the freezer $\left(-4\right.$ to $\left.-8^{\circ} \mathbf{C}\right)$ for one week despite the changes of some macronutrients and micronutrients that was found to be of little significance from the nutrition point of view.

\section{Conflict of Interest}

The authors have no conflict of interest to declare.

\section{REFERENCES}

AOAC (2016)

Official Methods of Analysis. $16^{\text {th }}$ Edition, Association of Official Analytical Chemists, Washington DC.
Buss I; McGill F; Darlow, BA and Winterbourn, $\mathbf{C}(2001)$ :

Vitamin $\mathrm{C}$ is reduced in human milk storage. Acta paediatrica.; (Oslo, Norway: 1992). 90. 813-5.

\section{Butte NF; Garza C; Smith EO and Nichols BL.}

Human milk intake and growth in exclusively breastfed infants. J

Pediatr.1984; 104:187-195.

\section{Cavalli C; Teng C; Battaglia FC and Bevilacqua $G$ (2006): \\ Free sugar and sugar alcohol concentrations in human breast milk. J Pediatr Gastroenterol Nutr.; 42(2):215-21}

\section{Chang YC; Chen $\mathrm{CH}$ and Lin MC (2012):}

The macronutrients in human milk change after storage in various containers. Pediatr Neonatol.;53 (3):205-9.

\section{Chung, M-Y (2014):}

The Factors Affecting Human Milk Composition. Pediatrics \& Neonatology. 55, 421-422.

Curran SJ and Barness LA (2000): 
Nutrition: the feeding of infants and children. In: Behrman RE, Kliegman RM, Jenson HB, eds. Nelson textbook of pediatrics. Philadelphia, WB Saunders, :149-69.

\section{Egypt Demographic and Health} Survey (EDHS) (2014):

Ministry of Health and Population; El-Zanatay and Associates; ICF International; 2014

(https://dhsprogram.com/pubs/ pdf/FR302/FR302.pdf, accessed 20 February 2020).

\section{Ezz El Din S; Abd El Ghaffar EK;}

\section{El Gabry E; Fahmi WA and Bedair} RF (2006):

Is stored expressed breast milk an alternative for working Egyptian mothers? Gastroenterology and Nutrition; 42, pp 215-221.

Guendelman S; Kosa JL; Pearl M; Graham S; Goodman $J$ and Kharrazi M (2009):

$\begin{array}{lcr}\text { Juggling } & \text { work } & \text { and } \\ \text { breastfeeding: } & \text { effects of } \\ \text { maternity } & \text { leave and } \\ \text { occupational } & \text { characteristics. } \\ \text { Paediatrics; } 123: \mathrm{e} 38-46 .\end{array}$

\begin{abstract}
Hamosh LA; Ellis DR; Pollock TR and Henderson $P$ (1996):

Human breastfeeding and the working mother: effect of time and temperature of short-term storage on proteolysis, lipolysis, and bacterial growth in milk. Pediatrics, 97, pp. $492-498$
\end{abstract}

Hanna N; Ahmed K; Anwar M;

Petrova A; Hiatt $M$ and Hegyi T(2004):

Effect of storage on breastmilk antioxidant activity. Archives of Disease in Childhood - Fetal and Neonatal Edition; 89:F518F520

Howard BA and Gusterson BA (2000):

Human Breast Development. $J$ Mammary Gland Biol Neoplasia.; 5, 119-137.

ISO 12966-2. (2011).

Animal and vegetable fats and oils - Gas chromatography of fatty acid methyl esters- Part 2: Preparation of methyl esters of fatty acids. International Organization for 
Gihan FAhmad, Naglaa M Mostafa, Tayseer MA ElZayat, Ghada Z Soliman1, Eman A Al Morsi and Eman M Elhabashi

Standardization, Switzerland, $15 \mathrm{p}$. fluoride-methanol. $\quad J$ Lipid Research; 5:600-608.
ISO 15304. (2002).

Animal and vegetable fats and oils - determination of the content of trans fatty acid isomers of vegetable fats and oils - Gas chromatographic method. International Organization for Standardization, Switzerland, 20p.

\section{Lawrence RA (1999):}

Storage of human milk and the influence of procedures on immunological components of human milk. Acta Paediatr Suppl.; 88(430):14-8.

Lev HM; Ovental A; Mandel D; Mimouni FB; Marom $R$ and Lubetzky R (2014):

Major losses of fat, carbohydrates and energy content of preterm human milk frozen at $-80^{\circ} \mathrm{C}$. $J$ Perinatol.; 34(5):396-8.

\section{Morrison WR and Smith LM} (1964):

Preparation of fatty acid methyl esters and dimethylacetals from lipids with boron

\section{Muhammad I; Lestari A, Kurdanti $L$ and Mardiyati W (2016): \\ Nur. Effect of Temperature and Storage Duration on Lactose, Protein and Fat Content of Breast-Milk. Conference: International Conference on Health and Well-Being (ICHWB) https://www.researchgate.net/p ublication/305719232}

Neville MC; Morton J and Umemura $S$ (2001:

Lactogenesis. The transition from pregnancy to lactation. Pediatr Clin North Am.; 48(1):35-52.

Ogbuanu S; Glover J; Probst J; Hu ssey and Liu J (2011):

Balancing work and family: effect of employment characteristics on breastfeeding. J Hum Lact, 27, pp. $225-238$

Pardou A ; Serruys E ; MascartLemone $F$; Dramaix $M$, and Vis HL (1994) :

Human milk banking: influence of storage processes 
Impact of storage temperature and duration on nutritive content quality of Human Breastmilk

Gihan FAhmad, Naglaa M Mostafa, Tayseer MA ElZayat, Ghada Z Soliman1, Eman A Al Morsi and Eman M Elhabashi

and of bacterial contamination

on some milk constituents.

Biol Neonate.; 65(5):302-9.

\section{Pham Q; Patel P; Baban B; Yu J} and Bhatia J (2020):

Factors Affecting the

Composition of Expressed

Fresh Human Milk. Breastfeed Med.; 15(9):551-558.

Prentice A (1996):

Constituents of Human Milk. Food and Nutrition Bulletin; 17(4):1-10.

\section{Putu AP; Sidiartha LG and Pratiwi} IGAP (2019):

The effect of storage on energy, carbohydrate, fat, and protein content of breast milk. Bali Medical Journal. 8. 59. 10.15562/bmj.v8i1.823

\section{Schanler RJ (2010):}

The paediatrician supports breastfeeding. Breastfeed Med.;5 (5):235-6. The

\section{Soliman GZA; Mohamady MF;} Hashem AM; Mohamed Mk and Elwahed A (2020)

Egyptian Mothers' Breast Milk Home Bank: Nutritional and Microbiological Study.
Chemistry Research Journal, 5(6):180-188

\section{Thatrimontrichai A; Janjindamai} $W$ and Puwanant $M$ (2012):

Fat loss in thawed breast milk: Comparison between refrigerator and warm water. Indian Pediatr.; 49(11): 877880.

Thu HN; Eriksson B; Khanh TT; Petzold M; Bondjers G; Kim CNT, Thanh LN and Ascher H (2012)

Breastfeeding practices in urban and rural Vietnam. BMC Public Health; 12:964.

Vieira AA, Soares FV, Pimenta HP, Abranches AD and Moreira ME (2011):

Analysis of the influence of pasteurization, freezing / thawing, and offer processes on human milk's macronutrient concentrations. Early Hum Dev.;87(8):577-80

\section{Walingo MK and Mutuli LA} (2014):

Influence of maternal beliefs, attitude, and perceived behaviour on breast-feeding among postpartum mothers in 


\section{Breastmilk}

Gihan FAhmad, Naglaa M Mostafa, Tayseer MA ElZayat, Ghada Z Soliman1, Eman A Al Morsi and Eman M Elhabashi

Western Kenya. Pakistan $J$

Nutr.; 13:250-45.

\section{World Health Organization (WHO) statement (2011,1):}

Exclusive breastfeeding for six months best for babies everywhere. Available at: http://www.who.int/mediac entre/news/statements/2011/bre astfeeding_20110115/en/index. html [Date accessed: 9, 2011].

World Health Organization. WHO statement 2019; 2.
Exclusive breastfeeding for optimal growth, development and health of infants. Available at: https://www.who.int/elena/t itles/exclusive_breastfeeding/e $\mathrm{n} /[$ Date 16,2020$]$.

Zhang K; Tang L; Wang H; Qiu LQ; Binns $C$ and Lee $A$ (2015):

Why do mothers of young infants choose to formula feed in China? Perceptions of mothers and hospital staff. Int $J$ Environ Res Public Health. 2015; 12:4520-32. 
Impact of storage temperature and duration on nutritive content quality of Human Breastmilk

Gihan FAhmad, Naglaa M Mostafa, Tayseer MA ElZayat, Ghada Z Soliman1, Eman A Al Morsi and Eman M Elhabashi

Table (1): Baseline fresh Breast Milk Nutrient Values at Zero Hour Compared with International Reference Milk Nutrient Values:

\begin{tabular}{|c|c|c|c|c|c|}
\hline \multirow{2}{*}{\multicolumn{2}{|c|}{ Nutrients }} & \multicolumn{2}{|c|}{$\begin{array}{lccc}\text { Baseline } & \text { fresh Breast } & \text { Milk } \\
\text { Nutrient } & \text { Values } \text { (at } & \text { Zero } \\
\text { Hour) } & & & \\
& & & \end{array}$} & \multicolumn{2}{|c|}{$\begin{array}{l}\text { International reference } \\
\text { nutrient ranges for } \\
\text { mature breast milk } \\
\text { values (Curran et al., } \\
\text { 2015) }\end{array}$} \\
\hline & & Mean $\left({ }^{+}\right.$SD $)$ & Range & Mean & Range \\
\hline \multirow{3}{*}{$\begin{array}{l}\text { Macro- } \\
\text { nutrients }\end{array}$} & Fat & $3.701( \pm 1.09)$ & $2.10-6.40$ & 4.54 & $1.34-8.29$ \\
\hline & Protein & $1.83( \pm 0.59)$ & $1.24-3.51$ & 1.06 & 0.73-2.0 \\
\hline & Lactose & $5.81( \pm 0.38)$ & $5.20-6.67$ & 7.1 & $4.9-9.5$ \\
\hline \multirow[t]{3}{*}{ Vitamins } & Vitamin C mg/dl & $3.46( \pm 0.90)$ & $2.10-5.20$ & 5.2 & $0.0-11.2$ \\
\hline & Vitamin A mg/L & $0.37( \pm 0.06)$ & 0.28-0.49 & 0.61 & $0.15-2.26$ \\
\hline & Vitamin E mg/L & $1.39( \pm 0.10)$ & $1.22-1.55$ & 2.4 & $1.0-4.8$ \\
\hline
\end{tabular}

Table (2): Baseline Mean Values of Breast Milk Nutrients at Zero Hour and after 24

\begin{tabular}{|c|c|c|c|c|}
\hline \multicolumn{2}{|l|}{ Nutrients } & \multirow{2}{*}{$\begin{array}{l}\text { Mean at Zero } \\
\text { Hour }( \pm \text { SD }) \\
3.701( \pm 1.09)\end{array}$} & \multirow{2}{*}{$\begin{array}{l}\text { Mean after } 24 \\
\text { Hours }( \pm \text { SD }) \\
3.57( \pm \mathbf{1 . 0 8})\end{array}$} & \multirow{2}{*}{$\begin{array}{l}\text { P Value* } \\
0.71\end{array}$} \\
\hline Macro- & Fat & & & \\
\hline nutrients & Protein & $1.83( \pm 0.59)$ & $1.71( \pm 0.41)$ & 0.46 \\
\hline & Lactose & $5.81( \pm 0.38)$ & $5.68( \pm 0.37)$ & 0.270 \\
\hline \multirow[t]{3}{*}{ Vitamins } & Vitamin C mg/dl & $3.46( \pm 0.90)$ & $2.03( \pm 0.46)$ & 0.000 \\
\hline & Vitamin A mg/L & $0.37( \pm 0.06)$ & $0.33( \pm 0.06)$ & 0.049 \\
\hline & Vitamin E mg/L & $1.39( \pm 0.10)$ & $1.33( \pm 0.10)$ & 0.09 \\
\hline
\end{tabular}

Hours Storage in Refrigerator at $\left(4-6^{\circ} \mathrm{C}\right)$ :

$* P$ Value is considered significant if $\leq 0.05$ 
Gihan FAhmad, Naglaa M Mostafa, Tayseer MA ElZayat, Ghada Z Soliman1, Eman A Al Morsi and Eman M Elhabashi

Table (3): Baseline Mean Values of Breast Milk Nutrients at Zero Hour and after one week Storage in freezer at $\left(-4\right.$ to $\left.-8^{\circ} \mathrm{C}\right)$ :

\begin{tabular}{|c|c|c|c|c|}
\hline \multicolumn{2}{|l|}{ Nutrients } & $\begin{array}{l}\text { Mean at Zero } \\
\text { Hour }( \pm \text { SD })\end{array}$ & $\begin{array}{l}\text { Mean after } 1 \\
\text { week }( \pm \mathrm{SD})\end{array}$ & $\begin{array}{l}\mathbf{P} \\
\text { Value* }\end{array}$ \\
\hline \multirow[t]{3}{*}{ Macronutrients } & Fat & $3.701( \pm 1.09)$ & $3.43( \pm 1.08)$ & 0.43 \\
\hline & Protein & $1.83( \pm 0.59)$ & $1.70( \pm 0.38)$ & 0.39 \\
\hline & Lactose & $5.81( \pm 0.38)$ & $5.38( \pm 0.37)$ & 0.001 \\
\hline \multirow[t]{3}{*}{$\underline{\text { Vitamins }}$} & Vitamin C mg/dl & $3.46( \pm 0.90)$ & $1.22( \pm 0.42)$ & 0.000 \\
\hline & Vitamin A mg/L & $0.37( \pm 0.06)$ & $0.27( \pm 0.06)$ & 0.000 \\
\hline & Vitamin E mg/L & $1.39( \pm 0.10)$ & $1.23( \pm 0.11)$ & 0.000 \\
\hline
\end{tabular}

$* P$ Value is considered significant if $\leq 0.05$ 


\section{Impact of storage temperature and duration on nutritive content quality of Human} Breastmilk

Gihan FAhmad, Naglaa M Mostafa, Tayseer MA ElZayat, Ghada Z Soliman1, Eman A Al Morsi and Eman M Elhabashi

\section{تأثير درجة حراره التخزين ومدته على جودة المحتوى الغذائي لحليب الام}

جيهان فؤاد أحمد I ، نجلاء محمد مصطفى Y، تيسير محمد عبد الحميد الزيات ب، غادة زغلول سليمان ا، ايمان المرسي المرسيّ و ايمان معوض الهباشيء

$$
\begin{aligned}
& \text { ا ـ المعهد القومي للتغذية ـ القاهره ـ مصر }
\end{aligned}
$$

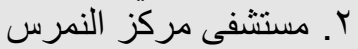

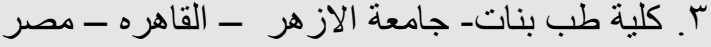

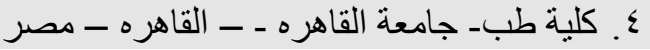

الملخص العربي

توصي منظمة الصحة العالمبة بالرضاعة الطبيعية الحصرية ، خلال الأشهر الستة الأولى من حياة الرضيع

، بسبب التركيب الفربي لحليب الثدي . بالنسبة للأمهات المرضعات العاملات ، بمكن أن تمثل معارسة الرضاعة الطبيعية الحصرية تحديًا. الأهداف: تقييم تأثير تخزين حليب الثدي في درجات حرارة ومدد مختلفة على محتوى لئي الدغنيات الكبيرة والدغنيات الدقيقة المختارة. الطرق: تم جدع ستبن عينة حلبب الثني في حاويات البولي بروبيلبين

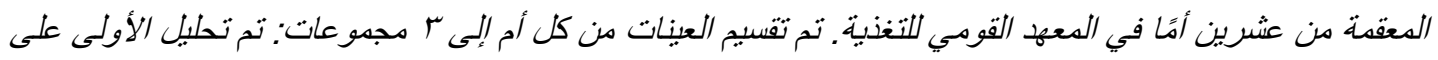

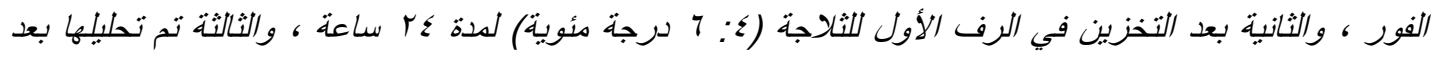

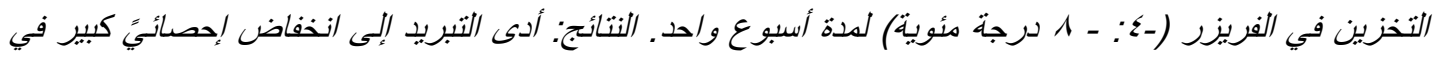
محتوى فيتامين أو ج و ه من حلبب الثدي بينما أدى التجميل إلى انخفاض إحصائيً كبير في محتوى حليب الثدي من الثن اللاكتوز, فيتامين أ, ج, ه. على الرغم من جميع الانخفاضات في المغنيات الكبيرة والمغنيات الدقبقة المدروسة , بقيت تركيزاتها ضمن النطاقات المرجعية الدولية المقبولة. الخلاصة: لا ينبغي إيقاف أو استبدال معارسة الرضاعة الطبيعية. تعتبر التغبير/ت التي حثت في حليب الثدي الدخزن ذات أهبية قلبلة من وجهة نظر التغذية. الكلمات المفتاحية: حليب الام- التخزين - الرضع- المرضع 